\title{
A Study of the Implementation of Internalized Interactive Multimedia Learning Models in Life Skills Education of Student at Primary School of it Al-Fitrah Binjai
}

\author{
Epi Supriyani Siregar \\ Universitas Pembinaan Masyarakat Indonesia Medan, Indonesia \\ episuprisiregar1216@gmail.com
}

\begin{abstract}
Education is a form of human culture which is a prerequisite for development. Therefore, it is necessary to implement life skills education in learning with the intention of integrating life skills through the implementation of interactive multimedia-based learning models. This study aims to determine the effectiveness of interactive multimedia-based learning models internalized in life skills education that can improve learning outcomes of students in thematic lessons. This research uses a qualitative research approach. Data are analyzed using descriptive analysis techniques to determine the effectiveness of interactive multimedia based learning models in life skills education. The results show that the implementation of an interactive multimediabased learning model with internalized life skills education involve the realm of personal skills, namely smiling, greeting, and being polite every day in the school environment at primary school of IT Al-Fitrah Binjai. On the other hand, the realm of academic skills involve the variants of learning methods by developing skills that are adjusted to the basic competency standards on the subject of teaching and learning activities. Internalized interactive multimedia-based learning models in life skills education can improve cognitive abilities, affective, and psychomotor students. By internalizing life skills education can improve student learning outcomes, so it is very effective to use.
\end{abstract}

Keywords interactive multimedia; life skill; multimedia learning models

\section{Introduction}

Education needs to be oriented towards the process of solving problems that are fundamental in the lives of students. The development of students' potential is taught to be brave, capable, and happy to improve their nature as caliphs on earth so that they are motivated to care for themselves and their relationship with God Almighty, society, and their environment. Changes or developments in education are things that should happen in line with cultural. Changes in the sense of improving education at all levels need to be carried out continuously in anticipation of future interests (Trianto, 2010:1).

According to Sugiharto (2020) education is one of the efforts to improve the ability of human intelligence, thus he is able to improve the quality of his life. Regarding with the implementation of life skills education in students, it is necessary to make an effort that can improve the methods used by the teacher in learning so that this can be realized. An inserting exemplary is a possible way so that students can internalize life skills education in their life. Life skills education is education that provides personal, social, intellectual, and vocational skills for work or independent business (National Eduication Department, 2004: 45). 
Thematic learning in elementary schools is one of the lessons that can instill life skills education in students. However, in implementing the learning process at primary school of IT Al-Fitrah Binjai, they do not pay much attention to this. Arsani (2020) stated that learning is essentially a cognitive process that has the support of psychomotor functions. The learning and assessment process emphasizes very limited instructional aspects, namely the mastery of the material (content mastery) which focuses on the cognitive dimension, so that it has neglected the other side that is also important, namely internalizing life skills education to bring up the affective and psychomotor dimensions of students. Waluyandi (2020) stated that the competence of teachers in establishing communication and cooperation with parents is still minimal. It is due to the teachers at SD IT Al-Fitrah Binjai consists of four teachers who have irrelevant educational backgrounds to elementary school teachers so they pay less attention to the importance of integrating life skills education in the learning process. Therefore, it is necessary to use various models, strategies, and good learning methods that can provide changes in the learning process in the classroom. This is intended that students do not only acquire knowledge but also acquire learning that is oriented towards affective and psychomotor aspects.

Internalizing life skills education can be applied in various ways, through learning models, methods, and learning strategies that are not monotonous. It refers to the cultivation of attitudes. This study develops two kinds of life skills, personal and social skill. Personal skill includes self-knowledge and thinking skill, while social skill includes communication and cooperation skill using interactive multimedia-based learning models.

Furthermore, based on the results of observations at SD IT Al-Fitrah Binjai, it is found that to support the learning process, the school provides adequate facilities such as blackboards, worksheets, and LCD projectors. However, at the time of learning biology, they have not optimized the existing facilities so that students have not mastered the learning materials properly. The available facilities do support learning in the classroom. In addition to that, internet network is also available in that school. However, the internet network is underutilized by educators as a supporting visual media that makes it easier for students to understand learning well.

The interactive multimedia-based learning model emphasizes that students are trained to internalize life skills education so that they are accustomed to doing an activity that can become a habit inherent in students. It becomes individual values. Learning multimedia has advantages over other media, it is due to the complete incorporation of computer technology from multimedia learning, audio and video is combined well. It can increase the attention of students to the information conveyed (Hardiyantari, 2017: 78). Interactive means that there is feedback given by the media to students who give orders to the media used. Multimedia can be packaged and its function is optimized to improve the abilities of students when combined with the right learning model.

Thus, it triggers to conduct research on the implementation of interactive multimedia-based learning models with internalized life skills education. This activity is a learning package with learning strategies and programming of learning materials that are suitable for use in class in improving student learning outcomes. This study aims to internalize life skills education through interactive multimedia-based learning models in thematic learning at primary school of IT Al-Fitrah Binjai and it applies learning through interactive multimedia-based learning models to improve learning outcomes in thematic learning at primary school of IT Al-Fitrah Binjai. 


\section{Review of Literatures}

\subsection{Life Skill Education}

Life skills education is a variety of skills to be able to adapt and behave in a positive manner. It enables a person to be able to face various demands and challenges in daily life effectively. According to Slamet (2008: 54), life skills are abilities needed by a person to live happily. Satori explains that life skills education is a life term, not merely having certain abilities (vocational job), however, it must have basic functional abilities such as reading, writing, formulating and solving problems, managing resources, working in teams, continuing to learn in the workplace, using technology. Life skills education programs are education that can provide practical, used skills related to the needs of the job market, business opportunities and economic or industrial potential in society (Anwar, 2006: 20).

National Education Department (2004: 12) provides an understanding of life skill education. It is integrated in subjects through the skills that students have to face life problems naturally without feeling pressured. It is proactive and creative to find a solution in order to be able to handle it. Furthermore, the Ministry of National Education (2004: 12) has 4 (four) skills which are stated as follows: (1) Personal skills are skills possessed by a person to have awareness of their existence and awareness of their potential; (2) Social skills are skills that a person has to be able to communicate verbally, communicate in writing, and work together; (3) Academic skills are called intellectual skills or scientific thinking skills which are basically the development of general thinking skills, but lead to scientific activities; and (4) Vocational skills are associated with certain fields of work in the community or environment of students.

Life skill education is given thematically regarding real-life daily problems. The themes that are set must be truly meaningful for students, both for now and for future life (Adhiambo, 2013: 57 ). The approach used is problem solving in a case that can be linked to several other subjects to strengthen the mastery of certain life skills. Students' daily life problem solving approach becomes more trained to face real life.

Learning methodologies can be designed in the form of activities that combine classroom learning and practice in the field and are carried out in a participatory manner with lecture methods (30\%). The rest are simulations, practices, group discussions and games (Suryadi and Tilaar, 2013: 179). The lesson hours that have been taught so far, for certain lesson hours it is necessary to agree on the reduction to be reallocated as a contribution to life skill education activities into a collection of lesson hours to discuss certain themes together with all related subjects.

Based on the explanation above, it can be concluded that the application of life skills education in schools requires careful planning, preparation, and implementation, as well as evaluation of the programs that have been implemented as the results to determine the next policy of the school.

\subsection{Interactive Multimedia}

Multimedia is a combination of several media components displayed via a computer and a display device (monitor or projector). Media display on a computer is digital and then forms an image that is transmitted by electron light which is contained in a viewing tool. According to Riyana (2007: 5), multimedia is a learning tool that contains material, methods, limitations, and ways of evaluating which are designed systematically and attractively to achieve the expected competencies in accordance with the level of complexity. Rusman, et al (2011: 296) state that multimedia is the use of computers to 
combine text, graphics, audio, moving images (video and animation) into one unit with the right links and tools so that multimedia users can navigate, interact, and create, and communicate.

According to Arsyad (2013), multimedia consists of four factors, namely: (1) there is a computer that coordinates what is seen and heard; (2) there is a link that connects users with information; (3) there is a navigation tool that helps users explore interconnected information networks; and (4) multimedia provides a place for users to collect, process, and communicate information with ideas in an interactive manner. If one component is missing, it is not interactive multimedia in the broad sense of the name. For example, if there is no computer to interact with, then it is mixed media, not multimedia. If there is no navigation tool that makes it possible to choose the course of an action then it is called a film, not interactive multimedia. Likewise, if you don't have the space to create and contribute your own ideas, then it's called television, not multimedia.

Based on the above understanding, it is concluded that multimedia is a combination of text, images, graphics, sound, animation, and video to create a dynamic presentation. It controls various multimedia elements to enable users to navigate, interact, create and communicate. The existence of multimedia can help teachers to design learning creatively. With a creative learning design, it is hoped that the learning process will be innovative, interesting, more interactive, and more effective. The quality of student learning can be improved and the teaching and learning process can be done anywhere and anytime. Moreover, students' attitudes and interest in learning can be improved.

\section{Research Method}

\subsection{Place and Time of Research}

This research is conducted at SD IT Al-Fitrah Binjai. The choice of this place is based on the consideration of the ease of obtaining data, the researchers focus more on the problem to be studied. Meanwhile, the time of this research is conducted from October to December 2020.

\subsection{Types of Research}

To conduct a study, an appropriate research method is needed to get a conclusion. The use of research methods is adjusted to the objectives and research situation so that the tools or techniques used can be determined. This research uses descriptive research with a quantitative approach. This research method is chosen to obtain a clear and real picture of the implementation of interactive multimedia-based learning models internalized life skills education.

\subsection{Research Subjects and Objects}

The subjects of this study are teachers, school principals, and students at primary school of IT Al-Fitrah Binjai. The research instruments used in this study are a questionnaire and a list of interviews. While several data collection techniques are carried out with the following objectives: interviewing techniques and questionnaire distribution are used to obtain data from both teachers and students about the difficulties, the learning resources used, and the perceived results and everything related to the implementation of interactive multimedia-based learning models. Internalized life skills education starts from the planning, implementation, and evaluation processes to improve the cognitive, affective, and psychomotor abilities of students. 


\subsection{Data Analysis Technique}

The data analysis method used in this research is quantitative descriptive analysis. The data obtained in this study are carried out in a quantitative way. Data originating from documentation is processed by means of documentation analysis. Data or information from the field obtained through questionnaires and observations is described using quantitative analysis through descriptive statistics to be selected and classified based on their importance.

\section{Results and Discussion}

\subsection{Results}

The findings of research in the field show that all parties at primary school of IT AlFitrah Binjai support the existence of life skills education through interactive multimedia learning in thematic lessons. This is done through good and careful planning. The planning begins with the preparation of a program for the existence of life skills education properly. In this study, the data are analyzed based on the implementation of interactive multimediabased learning models internalized life skills education in the implementation of learning, namely regarding active, independent, critical, solution-based learning. problems, life skill-based learning patterns, the use of learning characteristics adapted to competency characteristics and the application of learning which are summarized in preliminary activities, core activities and closing activities carried out during teaching and learning activities.

MY says that the implementation of life skills education at primary school of IT AlFitrah Binjai, by analyzing several school programs that support the cultivation of student soft skills for the preservation of the school environment and the natural surroundings. As a party of school, he hopes that every teacher must have prepared how to instill good attitudes for the academic community and the natural environment. It can be imitated by students so that a comfortable, effective and certainly Islamic teaching and learning process is created.

In the life skills education program at primary school of IT Al-Fitrah Binjai, researchers asked MY questions to find out about the program. It deals with the existence of a life skills education program in thematic lessons at primary school of IT Al-Fitrah Binjai. Regarding the existence of a life skills education program, the response is good, and in his opinion it is appropriate to include it in thematic lessons. In addition, in the general context, namely in the community, but also in special contexts including the aspect of amaliyah, namely the habituation that students must do in school. Clarifying the life skills education program at primary school of IT Al-Fitrah Binjai, then the researcher asked a question about the results obtained from the program. MB answers that the result is a form of content that becomes a focal point that can be applied and felt and practiced anywhere.

Researchers give questions to informants during the interview, about how the process of life skills education in thematic lessons at SD IT Al-Fitrah Binjai. The implementation of the life skills education process in thematic lessons is through habituation carried out by students such as 4S (senyum, sapa, salam santun) which means smile, greetings, and politeness in the morning and in the classroom which includes soft skills. On the other hand, for hard skills students are trained to become team leaders when there is group assignment in class or outside of class, because basically the 2013 curriculum is thematically integrated, so the output can balance students' life skills 
between soft skills and hard skills, it is explained by MG in answering questions from researchers.

Furthermore, MG explains more about life skills education in thematic lessons, the aspects of life skills that will be developed and integrated. It is a part of the basic competencies that must be pursued together with the achievement of skills that come from the subject matter of thematic lesson. It is poured into the form of an annual and semester program, mapping SK-KD, aspect indicators, syllabus and lesson plans. Before the teacher designs learning activities, they must first ascertain what life skills they want to develop on the subject matter in thematic lesson. It is adapted to the abilities and needs of students and the teacher concerned deliberately includes them as basic competencies and designs them into learning activities.

The researcher asks MB about the steps taken by the school regarding the life skills education program. MB answers that in instilling life skills education, the easiest is soft skills, through the habituation of good attitudes at school, namely in learning activities by all subjects and with other school programs. Teachers and school principals must be accustomed to being kind to all creatures, so that it will make it easier for children to imitate.

Related to the constraints of life skills education programs, the researcher asked LN as the classroom teacher about the obstacles in life skills education in thematic lessons at primary school of IT Al-Fitrah Binjai. LN explains that the obstacle for students is the IQ level of the students. Therefore, teaching them must be patient and often reminded of any irregularities in school.

Thus, it is concluded that the interactive multimedia-based learning model internalized life skills education can improve student learning outcomes, if the learning implementation process is always accompanied by life skills education such as: (1) SelfAwareness Skills which includes ; a person's ability to worship according to their religion, be honest, work hard, be disciplined, tolerant of others, and care for the environment, (2) thinking skills which include; the ability to dig and find information (Information Searching), information processing skills, ability to make decisions (Decision Making), and problem solving skills (Creative Problem Solving Skill), (3) communication skills which include oral communication skills and written communication skills, (4) cooperation skills which include mutual respect skills, mutual understanding skills, and mutual assistance skills. For student learning outcomes skills are measured through cognitive aspects after the end of learning which is done individually.

\subsection{Discussion}

Data on the implementation of interactive multimedia-based learning models internalized life skills education in learning planning at primary school of IT Al-Fitrah Binjai is measured through questionnaires, interviews, and observations. This finding confirms that using interactive multimedia learning models is an effort to internalize life skills education. Students are one of the creative efforts of the teacher in creating an attractive learning atmosphere for students. In addition, an active, interesting and comprehensive learning process can be carried out well. Through the process of discussion and presentation, students can practice teamwork and confidence and increase their knowledge.

Analysis of the implementation of life skills education through interactive multimedia learning in thematic lessons based on the findings of research data in the field, it shows that all parties at primary school of IT Al-Fitrah Binjai fully support the existence of life skills education through interactive multimedia learning on thematic lessons. Based 
on the implementation of life skills education through interactive multimedia learning in thematic lessons at primary school of IT Al-Fitrah Binjai an interview quote from the class teacher, Implementation of the life skills education process in thematic lessons is the habits carried out by students such as $4 \mathrm{~S}$ (senyum, salam, sapa,santun) which means smile, greetings, and politeness in the morning and in the classroom which includes soft skills.

The presentation of the findings above is in line with Naim's theory (2012) which argues that life skills education is defined as an activity that aims to carry out education in developing (1) a person's psychosocial abilities to overcome various kinds of demands and challenges of daily life, ( 2) a person's ability to maintain mental well-being through the ability to adapt to other people, culture, and the environment. In the process of implementing life skills education through interactive multimedia learning on thematic lessons at primary school of IT Al-Fitrah Binjai refers to data with a combination of strengthening theories, that the implementation of life skills education through interactive multimedia learning on thematic lessons is determined. From habituation by students according to what has been programmed in a well structured manner from the school. Hence, life skills at primary school of IT Al-Fitrah Binjai are included in the realm of personal skills.

Based on research data of the implementation of life skills education through interactive multimedia learning in thematic lessons at primary school of IT Al-Fitrah Binjai and an interview quote from a class teacher, Implementation of the life skills education process in thematic lessons with methods developed skills that are adjusted to the basic competency standards on the subject. In line with the explanation of the interview, it can be seen that life skills education is a fundamental reorientation of education, so in the aspect of school management it is also necessary to pay attention to the equalization of understanding among all school members. The realization of life skills education becomes one part of the school's vision, teachers or others in order to be able to realize life skills education in daily school life (Najid, 2012:33).

The process of implementing life skills education through interactive multimedia learning in thematic lessons at primary school of IT Al-Fitrah Binjai combines various variants of the methods used by the teacher during learning that supports the implementation of these skills education by students. Life skills at primary school of IT Al-Fitrah Binjai are included in the realm of academic skill. Based on research data about the process of implementing life skills education through interactive multimedia learning on thematic lessons at primary school of IT Al-Fitrah Binjai and an interview quote from the principal, the process of implementing life skills education is carried out in accordance with learning tools. It teaches the character habituation of good and polite attitudes which students do every day in class with the class teacher or the principal during the learning process.

It is in line with Phoebe's theory (2013) which states that life skills are given thematically regarding real-life daily problems. The themes that are set must be truly meaningful for students, both for now and for future life. Based on this explanation, it can be concluded that the implementation of life skills education through interactive multimedia learning in thematic lessons at MI NU Tholibin Tanjung Karang, it is determined from the learning tools that have been made by the teacher and teaches selfrefraction both inside and outside the academic community. Thus, life skills at MI NU Tholibin Tanjung are included 2 domains, academic skills and personal skills.

The point of research on the implementation of life skills education through interactive multimedia learning in thematic lessons at primary school of IT Al-Fitrah Binjai, it is concluded that the three schools fully support the existence of life skills 
education through interactive multimedia learning on thematic lessons, with the application of integrated life skills education through thematic lessons with the achievement of each indicator in schools, namely through learning activities outside the classroom, school environment and practice in daily life. This is in line with the development of the Ministry of National Education (2004), education is integrated into subjects through the skills possessed by students to face life problems naturally without feeling pressured, it is proactive and creative to find solutions so that they are finally able to overcome them. Three schools are in accordance with life skills education which is included in the realm of academic skills and personal skills.

The learning model must be adjusted to the mindset of students in order to get results in accordance with the learning objectives designed in the instructional learning objectives. In its application in the learning process, internalizing life skills education is more useful when applied using an interactive multimedia learning model with a discussion method and followed by a presentation where this method is in the dramatized presentation category. Activities like this certainly make students active as theorized by constructivism learning theory where good learning is defined as active learning and plays a full role in the process of acquiring new knowledge. Learning is also a social activity where students are required to discuss and help each other. This can be seen from the learning process that occurs when using the interactive multimedia learning model where students appear active and confident in appearing in front of their friends. In addition, they are also trained to work together with teammates in solving problems and finding solutions to problems. After finishing the presentation, there are some of the students who actively ask and express their opinions about the presentation they have just witnessed. The findings in this field prove that practically the interactive multimedia learning model is able to present active learning in accordance with good learning methods.

The supporting factors in the implementation of life skills education through interactive multimedia learning include: (1) the seriousness of students in learning to be better, because they are motivated by highly dedicated teachers who provide good examples to them both at school and outside of school and (2) there is funding, so that the facilities and infrastructure for practicing thematic lessons outside the classroom, both tools and materials are fulfilled properly.

\section{Conclusion}

In general, the conclusion from the results of this study is that the implementation of interactive multimedia-based learning models with internalized life skills education has been carried out by the teacher, centered on students and given the freedom to actively argue and give time to practice directly. The implementation of life skills education uses individual principles and is closer to students so that it can be conveyed properly. The method used by the teacher is the method of practice outside the classroom (outdoor learning) with a combination of learning. The results of several stages of research that have been carried out in Class IV shows that primary school of IT Al-Fitrah Binjai needs teacher innovation and creativity in the learning process due to the low cognitive, affective and psychomotor abilities of students, especially to internalize life skills education when learning in class. Therefore, the researchers use an interactive multimedia-based learning model with internalized life skills education as an alternative learning innovation. The results showed that the interactive multimedia-based learning model of life skills education can improve student learning outcomes, if the learning process is always accompanied by life skills education, such as: (1) Self-Awareness Skills which includes a person's ability to 
worship according to their religion, be honest, work hard, be disciplined, tolerant of others, and care for the environment, (2) thinking skills which include the ability to dig and find information (Information Searching); information processing skills; ability to make decisions (Decision Making); and problem solving skills (Creative Problem Solving Skill); (3) communication skills which include oral communication skills and written communication skills, (4) cooperation skills which include mutual respect skills, mutual understanding skills, and mutual assistance skills. For student learning outcomes skills are measured through cognitive aspects after the end of learning which is done individ ually.

In addition, the interactive multimedia-based learning model of life skills education can optimize student learning outcomes, if during the implementation of learning the teacher delivers material by integrating life skills education and guides students to get used to applying it in everyday life. The results of this study can be used as a basis for further research by integrating different learning or different themes.

\section{References}

Adhiambo, L. Phoebe, 2013. "Implementation of Life Skills Education in Secondary School in Uriri and Awendo Districts Migori County Kenya", Journal Information Bulletin, No. 9 (2013), 57.

Anwar. 2006. Life Skills Education. Bandung: Alfabeta Bandung.

Arsani, et.al. (2020). Differences in Motivational Orientation in Physical Education in terms of Gender Differences. Budapest International Research and Critics in Linguistics and Education (BirLE) Journal Vol 3 (3): 1428-1434.

Arsyad, A. 2013. Learning Media. Jakarta: PT. RajaGrafindo Persada.

Ministry of National Education, 2003, Law Number 20 of 2003, Concerning the National Education System, Jakarta: Depdiknas.

Depdiknas, 2004, Development of Life Skills Education, Jakarta: Depdiknas.

Hardiyantari, Oktavia, 2017, "Development of Interactive Learning Multimedia Using Dynamic Techniques in Productive Subjects in Computer and Network Engineering for Class X Students." Journal of Educational Technology Innovation, V4 No.1.

Law of the Republic of Indonesia of 2003 concerning the National Education System. Jakarta: Karya Gemilang.

Naim, Ngainun, 2012, Character Building Optimizing the Role of Education in Science Development and National Character Building, Yogyakarta: Ar-Ruzz.

Najid, Mohal, 2012, Life Skills through a Broad-Based Educational Approach, Surabaya: Intellectual Club.

Phoebe, L. Adhiambo, 2013. "Implementation of Life Skills Education in Secondary School in Uriri and Awendo Districts Migori County Kenya”, Journal Information Bulletin, No. 9, 2013, 57.

Riyana, Cheppy. 2007. Guidelines for Video Media Development. Bandung: Indonesian Education University P3AI Program.

Rusman, et al, 2011. Learning Based on Information and Communication Technology: Developing Teacher Professionalism. Jakarta: Raja Grafindo Persada.

Slamet PH, 2008, Life Skills Education in Elementary Schools: Concept and Implementation, Jakarta: Directorate of Elementary Schools.

Sugiharto (2020) Geographical students' learning outcomes on basic political science by using cooperative learning model with Group Investigation (GI) type in State University of Medan, Indonesia, Journal of Human Behavior in the Social Environment, 30:4, 447-456, DOI: 10.1080/10911359.2019.1696261. 
Suryadi, Ace and H.A.R Tilaar, 2013, An Introduction to Educational Policy Analysis, Bandung: PT Remaja Rosdakarya.

Trianto, 2010. Designing an Innovative-Progressive Learning Model: Concept, Foundation and Implementation at KTSP, Jakarta: Kencana Prenada Media Group.

Uno, Hamzah B. 2010. The Education Profession (Problems, Solutions, and Educational Reform in Indonesia". Jakarta: Bumi Aksara.

Waluyandi, F., Trihastuti, R., and Muchtarom, M. (2020). Implementation of Parental Involvement in Learning Civic Education. Budapest International Research and Critics in Linguistics and Education (BirLE) Journal Vol 3 (4): 1686-1695. 